This item was submitted to Loughborough's Research Repository by the author.

Items in Figshare are protected by copyright, with all rights reserved, unless otherwise indicated.

\title{
The telephone and the social struggles in Turkey: An overview of a social history of a communication technology
}

PLEASE CITE THE PUBLISHED VERSION

http://www.cyberorient.net/article.do?articleld=9190

\section{PUBLISHER}

(C) American Anthropological Association

\section{VERSION}

AM (Accepted Manuscript)

\section{PUBLISHER STATEMENT}

This work is made available according to the conditions of the Creative Commons Attribution-NonCommercialNoDerivatives 4.0 International (CC BY-NC-ND 4.0) licence. Full details of this licence are available at: https://creativecommons.org/licenses/by-nc-nd/4.0/

\section{LICENCE}

CC BY-NC-ND 4.0

\section{REPOSITORY RECORD}

Celik, Burce. 2019. "The Telephone and the Social Struggles in Turkey: An Overview of a Social History of a Communication Technology". figshare. https://hdl.handle.net/2134/25306. 


\title{
The Telephone and the Social Struggles in Turkey: An overview of a social history of a communication technology
}

\author{
Burçe Çelik, Bahcesehir University, Department of New Media, Istanbul
}

This essay presents an overview of social history of telephone technology in Turkey, by taking the user-perspective to its center. As part of the set of essays in this special issue dealing with the history of telephony in the non-west, this essay seeks to explore how the telephone has become part of social practices of people, how it has integrated into the social struggles of people and how it has been appropriated to convey the users' struggle to alter their positions in the social structure, assert their agencies and participate in the making of the modern throughout the history of modern Turkey. Rather than offering a detailed categorization, periodization and related narration of the life of the telephone technology in Turkey/Ottoman Empire, this article specifically focuses on some moments where the meanings and the uses of telephone in daily life practices and imaginations of people reflected and contributed to the mobilization of the social struggle in the form of class and/or ethnic and gender struggle.

The telephone is among the least studied modern communication technologies in Turkey as well as in other non-western countries. Although the social history of technologies, such as the telephone, has received significant scholarly attention in various disciplines within the fields of social sciences and humanities, the focus of the researches has largely been on the western territories, mostly due to the fact that the design, innovation and the production of these technologies took place in the US and central Europe. Yet, the use of these technologies were never limited to places where they were initially designed or invented but spread to different places, generating multiplicities, diversities and differences within the production of multiple modernities. Arguing that technologies become what they are as they become sites for social practices, by responding and reproducing the wills, desires, anticipations and inclinations of people, this project aims to produce an understanding of what is wrapped in the Turkish telephony. The telephone has long been a technology whose ownership and utilization in private spaces were limited to the privileged segments of society. Thus, this study attempts to give a glimpse of how the presence or absence of the telephone in people's homes affected social relations and contributed to the social dispositions in Turkey. The telephone was first introduced as a commercial service provided by an internationally owned company and then nationalized after the foundation of the Turkish Republic and remained as a state service until the mid 2000s. In this article, I sketch an overview of the history of the telephony as unevenly distributed state service and the resentments it created on the part of the larger unprivileged public. This dynamic, I suggest, also informs the collective appetite for technological novelties such as the cell phone that has become extremely popular shortly after it was introduced in the mid $90 \mathrm{~s}$ as a technology of communication whose use or ownership did not require the approval of the state authorities.

The research project that this paper is based on approaches the history of the telephone with a view that strives to put forward a social history example, which 
sustains itself from different sources and hence difference view-points (stateuser, owner and non-owner). The findings of the oral history research which we have conducted with more than 100 people living in four different cities in Turkey (Ankara, İstanbul, Kayseri, Diyarbakır) and the archival research, including the analysis of national newspapers, popular journals and Telecom institutional magazines will be used as the grounds of the analysis of the Turkish telephony. All of these sources, and especially the interviews with people, $40 \%$ of whom were over 60 years of age, belonging to the different social classes, owning differing social and political stands (Secularists, Islamists, Kurdish nationalists etc.) provide valuable hints about how telephony has been imagined and what was bound up in its performance in terms of collective desires, responses, purposes and wishes. However, this material on its own does not fully reveal the intricacy of telephony. As such, this paper only uses some of the examples gathered from the oral history and archival research, while it more focuses on the general analysis of how the telephone has attained its meanings within the social imaginary and collective practices in Turkey.

\section{Discussions of History of Modernity and Technology in Turkey}

Although the history of modernity in Turkey has been of great scholarly interest and although the modernization ideals and projects of Turkey and Ottoman Empire have been constellated technologically particularly in the sense that the adoption of techniques and technologies have always been integral to the modernization processes in Turkey, the study of technology has received little attention of the scholars. In works where the intrinsic link between the programs of modernity and the presumed and desired adoption of western technologies and techniques is underlined, technology has mostly been considered as a tool, machine or a symbol. Technology as tools, machines or devices have been said to be "transferred" to the Ottoman/Turkish territory as unfamiliar, novel and external things that would repair the failing and collapsing system of economic and political landscape along with the institutions that were in need of reforms and recovery (Lewis 2002, İhsanoğlu 1992, 1995). In that respect, communication and transportation technologies such as the postal system, the telegraph and railways of the $19^{\text {th }}$ century were seen as the futile attempts of the Ottomans to repair its failing and collapsing institutions, economic and political systems. Thus in that sense the telegraph was a machine of network that would centralize and unify the country of the Ottomans; the railways would bring new means of commerce and new connections with the European economic center; because they were imagined as such by the state rulers or represented as such in the rulers' and elites' discourses (Davison, 1990).

Accordingly historians of Turkish modernity, science and technology have taken these technologies as tools that have functioned always in ways that were planned and imagined by the state rulers and the adoption of these techniques and technologies by the Ottoman state revealed the changes in institutions of the Ottoman Empire or the Turkish Republic. The real functions of these 
technologies, such as the ways in which they were used by different agents, including ordinary people, businessmen, traders and state people were never of so much concern. Technology in general was what the rulers imagined them to be. Yet, the comprehensive and wider understanding of technologies show us that techniques and technologies have usually grown different from the expectations of their inventors and/or technocrats. For instance, the telegraph was adopted almost without a hesitation by the Ottoman sultan, which is a very atypical case, for it was thought to bring the means of control and centralization and yet it turned out to be of help for the dissolution of the Empire and the foundation of the new Republic as the successor of the Ottoman Empire.

In a similar manner, technologies have also become part of discussions in these works where as a general and abstract concept it is used as a symbol of westernization ideals in which the presumed time lag between the European and Ottoman/Turkish present is imagined to be filled with the speed and movement that is brought by modern technologies and science. After all technology was an applied science and had the capacity to bring what is missing to the landscape. Therefore whenever it is mentioned within the discourses of modernization projects, it symbolized the absolute ideal of westernization, and accordingly revealed desire for similarities with the western nation particularly in terms of the use of techniques and technologies. Historians considered technologies in that sense as symbols because techniques and technologies were in general understood as symbols for westernization, Occidentalism and/or selfOrientalism of the modernizing state rulers and elites of Ottoman/Turkey. However as the literature on multiple modernities suggest, "modernity and westernization are not identical; Western patterns of modernity are not the only 'authentic' modernities, though they enjoy historical precedence and continue to be a basic reference point for others" (2000: 2-3). Thus, although the use and domestication of "western" technologies contributed to the production of the modern in Turkey, the collective use of or desire for those technologies on the part of people should not be reduced to the discussions of westernization.

Although there are few works within critical Turkish studies that treat technologies as serious objects of cultural analysis such as Meltem Ahiska's (2005) work on early Turkish radio, media technologies in these studies remain to be analyzed only by focusing how they were imagined and put in operation for propaganda of Kemalist nationalism, secularism and modernization processes. In this regard, the way radio was used for spreading the Kemalist ideology by the rulers of the time provided the only explanation how Turkish society has been forced to incorporate the modernity ideals via the mediation of radio which functioned like an embodiment of the west that is paradoxically seen both as a model and a threat for Turkish identity. Or in literary criticism, the role of technology such as cars, clocks, engines in Turkish novels was analyzed and said to have paradoxical roles which reveal the imaginations of technology both as part of self, familiarity, desire, self-expression and also of other, unfamiliarity, fear and loss of self-presence. Even though these works were and are very instructive to understand how technologies have been imagined and obtained meaning in the modernizing elite's imaginary and the state's projects, they do not tell us much about how these technologies have been perceived, received 
and appropriated by the larger public. In the absence of this link of users of these technologies, we cannot fully understand the functions and meanings of these technologies and accordingly we miss the understanding of crucial components of everyday imaginations and experiences of modernity. Cultural studies of media and technology show us that each media text can be read and interpreted in various different ways though the methods of reading are always limited by historical conventions to a certain extent.

A technology is never only shaped by power structures but also not independent from it. Just as its use and meanings are determined both by the agency of users and also by the physical infrastructures, economic, social and cultural conditions that it is put to use in. In other words, neither modernity nor technologies are reducible to the projects and programs of the state or state elites' discourses. The fact that origins of modernity and modern technological inventions are not products of any particular country does not necessarily mean that technology and modernity are not generated in those people's life experiences through their agency and conditions they live in. As Jonathan Sterne (2003) remarks, technology is always at a given moment a social practice and implemented in social struggle. Technology finds its own meaning and use in practice, in rituals of people whose agency and intentions are in play much as the strategies and policies of the state are. Understood as such the study of technology enables us to come closer to a comprehension of how modernity is produced by ordinary people in their practices, by the state in their operations and projects, by physical and material conditions, and affectivities that are wrapped in intentions, desires, wills and purposes, and in social relations and through social struggles that may be manifested as cultural struggles, class struggles or identity politics. Taken as such analysis of social history of a technology might make us see the continuities and change, sameness and difference, unities and paradoxes in experiences of people and in discourses of the state and the state elites.

\section{The State and the Public}

The early history of the telephone in Ottoman/Turkish landscape which goes back to the 1880 s is illustrative to see how the life of this technology were to be structured with the struggles in Turkey. The struggle for the telephone use has largely started with the initiatives of businessmen and traders' who wanted to install lines between their residences and work places despite the strict governmental control of Sultan Abdulhamid II over public communications and communication technologies. Actually, the first appearance of telephony in Turkey appears to have taken place as early as 1877 when the Production Director of the Directorate of Telegraphy, Emil Lakvan, experimented with communicating over a telephone line of 500 meters length. The Istanbul press reported that the experiment was successful and a telephone line between a telegraph factory and a telegraph office would be established soon. Of note is the fact that, if the news is to be believed, Lakvan had himself "manufactured the telephone machine [used in the experiment] based on the invention of the American Graham Bell (Vakit, 1877)." 
Nevertheless, the establishment of telephone lines in Istanbul would not be realized until 1881. The first telephone line in the Ottoman capital Istanbul was established between the Ministry of Postal Services and a post office and the next one between a bank and one of its branches and a third one between two coastal ports of the city. However, all the lines except the one between the two ports were disbanded five years later. It is widely believed that the reason for this action was the deep suspicions of the ruling Sultan Abdulhamid II on new communication technologies, which could be utilized for subversive purposes. During the remaining years of the rule of the highly authoritarian Sultan Abdulhamid II, no new initiatives were taken to set up new telephone lines (Bektaş 2000, Onay 1995, Demir 2005). The Telephone Systems of the Continent of Europe (1895) notes that the proposals of French and other investors to establish telephone services in the Ottoman Empire were all rejected and speculates "political prejudices" in the ruling circles against telephony to be the reason for the blocking of penetration of this technology to the Ottoman lands.

Various records from the Ottoman Archives indeed provide documentation on the persistent stand of the authorities to prevent such a penetration. On the other hand, these documents also testify to a history of efforts to appropriate this technology despite the authorities' position, such as a communiqué addressed to the Interior Ministry, relaying information on the presence of telephones in the Black Sea coastal town of Samsun and calling for their seizures and prevention of telephone communications. There are also several records regarding seizures at the customs of telephone equipment to be imported into the country. The despotic Sultan Abdulhamid II would be deposed by the so-called Young Turks' revolution of 1908 and the revolutionary regime would soon initiate reestablishment of telephone services in Turkey. Tellingly, the Mail and Telegraph Ministry would be renamed as Mail, Telegraph and Telephone Ministry in 1911. In 1911, the British engineer and entrepreneur, Herbert Laws Webbe, was given the right to run the telephone company - Dersaadet Telefon Issletmesi- for 30 years. Yet after the First World War, this company was appropriated by the government and almost all foreign workers and managers working in this company were sacked (Alşan 1990).

It was only after the 1930 s that the telephone service became a state service that aimed to connect different parts of the nation to each other in accordance with the policies of the nationalization and modernization of the infrastructure as well as the everyday life culture of the country. Despite the state endeavors to increase the penetration of the telephone system and the policies that regard the technological development a necessary counterpart of modernization, progress and economic development, the total telephone lines in İstanbul (the biggest city of Turkey), İzmir (the third biggest city of Turkey) and Ankara (the capital city) were not more than 20.000 lines by 1935 (see Bezaz undated), while there were more than 3 million telephone stations, 48 thousand telephone kiosks were actively in use in the UK by 1938

(see http://www.britishtelephones.com/histuk.htm).

Starting from the early 1940s till the mid 1980s, the Turkish telephony as a state service was structured with the ownership of some and non-ownership of 
others. From the 1940s onwards, the political system has changed from a single party system to a multiparty system, from statist economy politics to liberal and neoliberal market economy. While statistics show that Turkey's telephone infrastructure did indeed develop somewhat from the 1960s onwards, (after the first economic development plan of the state), they unmistakably reveal that the actual gap between demand and supply nevertheless increased at a higher rate than the increase in supply. Clearly, the introduction of the telephone to more households was creating an appetite for telephony and resentment towards the state as the service provider in households without the telephone. Although Turkey adopted many technologies almost simultaneously with Europe, the feeling of being late to technological development and progress has never left the affective and cultural landscape of Turkey. This sense of belatedness also draws upon desires, aspirations and fears, envies and resentments toward the governments, which failed to bring the means of progress and economic stability to the country. Perhaps motivated by the fear and anxiety of being latecomers and by a desire to own the newest modern object, any adoptable technology has entered some people's lives at a high speed. While technologies were fascinating to many, their actual uses and possessions were limited to a small segment of society for so long (until the mid 1980s). Telephone technology, in this regard, has been the object of collective fascination and frustration, joy and fear, determinacy and hesitancy. On the one hand, the increase of the telephone penetration level was in the state programs especially after the 1960s; the intelligentsia and business circles also supported these economic programs to institute higher connectivity as a means to better trade and the public (particularly urban people) demanded and accepted to pay the taxes, prices and fees for telephone connection. On the other hand, the telephony as a state service could not fulfill the demand of the public (thousands of people's names were on the waiting lists for years) and even when the state instituted the telephone system in particular areas, the telephone connection was often so expensive, not high quality and forcibly short (telephone calls were limited to 3 mins until the mid 80s due to the few available telephone lines for an overcrowded population of telephone users). By 1962, there were 192.000 subscribers while there were 183.000 on the waiting list, by 1977 the numbers reached to 851.000 subscribers and 1.300 .000 people were on the waiting list (DPT Development Plans, 1996). Some of the headline examples from different years of the daily newspapers read as follows: "The telephone company still ignores the people's complains" (Milliyet, 1953); "60.000 people are still waiting to get a telephone line" (Hürriyet, 1959), "Turkey ranks among the least telephonic nation" (Hürriyet, 1960), "All are complaining about the high fees of telephone connection" (Hürriyet, 1972); "The unspeaking telephone” (Hürriyet, 1973).

Within this period where the non-ownership of the telephone has determined the very practices and feelings for the telephony system for the large public, people who were waiting for a telephone subscription for years were inclined to find some acquaintances working in the state organizations to accelerate the subscription processes, with a belief that favoritism plays a crucial role in the state management of subscriptions. Our oral history research has revealed that the telephone has been seen as an object of privileged ones who differ from the rest of the society on the basis of their financial capabilities (economic capital), 
their educational qualifications (intellectual/cultural capital) and through their hegemonic power over others (symbolic capital). In other words, the use of state telephony has historically been limited to the small segment of society who held the means of social, symbolic, economic and cultural capital.

Roughly starting from the 1980s, as the structure of social space has altered due to the increased integral migrations from rural areas to big cities, due to the newly adopted neo-liberal market economic system, and due to the fact that the third military intervention generated a new rationale for the state to surveil the citizens (particularly the dissidents) more effectively, the telephone has become more of a "useful and instrumental" technology for the state and for wider, larger public. The motto of the 1980s, "Turkey is opening to the world", was implying the role of technologies in this ambition. The organization of a national technoscape was seen as crucial for achieving the dream of making Turkey a body that could communicate and be compatible with its western counterparts. "Highways are liberty" announced Turgut Özal, the prime minister at the time, who was a crucial figure in the transition to a neo-liberal development model in the 1980s. He promised new highways, high penetration telephone lines and electricity and water to areas that have always economically, socially and politically marginalized. Transforming the technoscape was a necessary part of imagining and idealizing a civilized, modernized and unified Turkey. In an interview with the former Communication and Transportation Minister of Özal's government in the 1980s, the minister told us that "the telephone along with all telecommunication systems were crucial to institute a unified, safe and equal Turkey. The government was eager to establish this unified and modern technological landscape". This ambition has also implied the aim of the state to monitor and control the citizens' daily communications as well as to open the Turkish market to the global consumer and trade culture in the 1980s. Our oral history research findings also prove that the majority of users in Turkey consider the 1980s and Özal's government as the milestone for the Turkish technological development where the rapid increase of the telephone system was seen as the most evident example of the progress. The headlines of the popular national newspapers also demonstrate that the approval of the ambition to connect the national telecommunication system to the "civilized" and "progressive" world. Some of the examples are: "How do we compete with Europe in our telecommunications?" (Milliyet, 1982), "We're catching up with the civilized age in telephone systems" (Milliyet, 1986). The liberalization and commodification of the cultural landscape of the 1980s were also caricatured and ridiculed through the representation of telephone in daily cartoons where the telephone was depicted as an object of the corrupted, dirty and yet seemingly fancy lifestyle.

\section{Class, Ethnic and Gender Struggles via Telephony}

As embodied practices and also as possessions, technologies serve to distinguish one group from another and to produce commonalities between different people or groups in the same social space. A technology may well function as cultural and social capital, becoming a form of agency, prestige and control. The main idea of being in social space according to Pierre Bourdieu (1990) is to be different from others. The position one occupies, by possessing different kinds of 
capital, is integral to conserve or transform representations of social space. Although each technology refers to different bodily practices and social dispositions, technologies are in general integral to the habitus in the sense that they generate practices, are made up by these practices, and become means for positioning oneself in the world. The telephone in Turkey as a technology that has been unevenly distributed to the nation functioned like a cultural and symbolic capital differing the owners from others and generating envy and appetite for the property of telephone on others.

The uneven distribution of direct access to telephony has also given way to social practices of allowing others to make use of one's household telephony. Thus the telephone that was privately owned and placed in a private household was also a semi-public tool that generated its own practices where the task of the telephone owner was structured with the practice of sharing the property with others. The telephone in that sense has come with its own ethics and responsibility: the ones that had the means to have this technology needed to be responsible, good citizens and good neighbors willingly or unwillingly, happily or unhappily sharing the telephone with others. In this regard, the telephone whose status as private technology and a public one is blurred gave way to the practices where traditional -brotherhood, solidarity, communal life- and the modern technology, a personalized technology- are negotiated. The telephone functioned like a "gift" as one of our interviewees has told us, that is happily offered to the guests; it has also been considered a unwanted "burden" as another interviewee has expressed which created unnecessary traffic of neighbors in one's private place. The ones who owned a telephone when many others did not were in the position of offering the share of what they had and accordingly differed themselves from others in the very practice of social relations. The question of who used to own a telephone when many did not have was often answered in our oral history research with statements such as:

"The privileged ones... For instance, there was something called stateprivileged lines. It is like very privileged. Like you are VIP... Not everyone had a telephone. The state gave it to the people that it wanted to. That was it... But the resonation of this on the part of public was like class discrimination. Some were always imitating others, jealous of others who owned it. Admiration is a good thing, but envy, detest, jealousy... these are all very poisoning. And we lived this in those years". (A retired bank officer male informant in his 60s)

While the possession of the telephone has certainly associated with the economic capital of the owner, more importantly the telephone (like many other household technologies in Turkish context) has come to signify the cultural and symbolic capital of the possessor and her/his family. An example from a taxi driver from Kayseri in his 50s remembers those days as:

Q: Do you remember the telephone from your years in Kayseri?

A: Only my uncle had it. The ones who had the telephone were mostly seen as rich people. We used to say "he even has a telephone". $\mathrm{Q}$ : So it was an issue of conversation? 
A: Yes, of course. My uncle for example was a state officer in Kayseri.

A: Was he rich?

A: No, actually. But we used to think that he was an important person. Q: Why?

A: Well, because he had a telephone in his flat. And we came to Kayseri from a little village. His clothes, his family etc. were all reflecting his status. He had daughters and they were going to school and actually those girls helped me with my homework. We kind of looked up to them.. The whole family I mean.

Thus, the "significance" and the social power that the telephone brought to the household was not necessarily related to the wealth or economic capital of the possessors, but rather with the urban and modern lifestyle, education and taste which we could categorize in accordance with Bourdieu's theory as cultural capital. The telephone was a symbol and representation of cultural and symbolic capital within the understanding of the public and yet the same sort of representations were also common in popular publications, including the newspapers, film posters, journals etc. It is so common to see the photographs of politicians in print news, or artists in celebrity magazines, or people in ads of toothpaste, banks or any other unrelated businesses with a telephony system all of whom were represented with the telephone although the contents of the news, ads or story are completely unrelated to the telephone. This also shows that the telephone was truly a cultural artifact that has fully integrated into the national imaginary, symbolizing modern and urban values, lifestyle and thereby cultural capital. Thus the appetite and desire for telephony was not only based in practical and instrumental incentives for the use of "necessary technology" for everyday life practices but also conditioned with motivations and desire for social mobility.

Other than class struggle and differences, the telephone has historically been integrated into identity-based struggles such as gender and ethnic identities. As other studies in different national contexts show, the telephony has historically been associated with the voice of the operators working in the centrals (Karakışla 2008). Operators in Turkey, like many other countries, were mostly women, for whom the telephone companies initially of European based firms and then of the state meant the opportunity to work in non-domestic places. The history of Turkish telephony within the context of feminist struggles has also a special significance: while the telephone service was introduced to the Ottoman society by European telephone companies, the managers of the company preferred to hire non-Muslim women as central operators probably due to the seeming impossibility of hiring Muslim women as workers at the turn of the 20th century Ottoman society (ibid). However, some Muslim, modernist and elite women protested the policies of this western company with a complain that a company serving for Ottoman people in the Ottoman soils must produce opportunities of jobs for women without a discrimination based on their religious and ethnic identities. Although, this protest was more nationalist oriented in essence, resonating the period's popular nationalist ideology of the Turkish elites, it is considered as one of the first protests of Muslim women in the history of Ottoman and modern Turkey (ibid). After the second initiation of 
the telephone service in Turkey following the suspension of the ban on telephone service in the 1920s, the operators have become like extensions of the state telephony in the eyes of the users till the establishment of the automatized central system in the mid 1990s of Turkey. The operators were there to connect the local and the international calls, functioning like constant eavesdroppers as they connect two ends via cables. Throughout the most of the history of telephony in Turkey as an object possessed by only limited people, the operators were also there to interrupt the telephonic connection when the talk exceeded 3 min limits. The operator, as the voice and human extension of the state telephony system, was also forced to give an ear to the furious complaints, resentful speech, or even the curses of the customers who had to wait for hours or days to make the connection with others due to the deteriorated telecommunication infrastructure. The oral history research with the former central operators showed us that working in the central required a psychological strength and resilience to bear the constant complaints of the users who could not find any other agent to voice their resentment and frustration about the lack of good telephonic interaction system. On the other hand, the research that we have done in the archives of Turkish Telekom (previously PTT) journals also showed that almost each issue of this journal (namely PosTel) contained articles in which the operators were either presented as the face, voice, body of the telephone system and accordingly as the ones who must act politely and be caring to make the customers happy. In other words, the work of female operator in Turkey has truly been defined as an affective labor which required the production of the "state of being" -as caring, soothing and polite female beings- of the state-run telephony system.

As the operator functioned as the necessary third party to sound connection of telephony, she was also forced to take up the monitoring function of the state at times. Particularly during the militarist history of Turkey, where the leftist dissidence and the Kurdish nationalist political struggle were strictly repressed by the Turkish governments (during the 70s and 80s), the operator was also given the role of a spy, informing the state organs where the users speak Kurdish (when the use of Kurdish even in private spheres and communication was prohibited under the rule of militarist government) or the "suspicious" ones make or receive a call from other ends. One former operator working in Diyarbakır in the late 80s under the rule of Emergency State Policies recounted her professional experiences with a striking story as follows:

"A woman, a mother from a village of Diyarbakır wanted to call her son who was doing his military service somewhere else. The woman, just as many other elder women in the region, did not know Turkish. She had waited for days to get a line to call her son. Finally, I connected the line, but the woman of course spoke Kurdish to her son. My job was to cut the talk, but I couldn't. How could I? I am a mother myself... then I translated everything she said to Turkish and then from Turkish to Kurdish as her son spoke. It was one of my sad memories of the time.

\section{Conclusion}


This paper argues for the need to contextualize the study of telephony within the local and historical social struggles of owners and non-owners of the telephone which manifested itself through the meanings given to the telephone as a political, social and cultural artifact that integrated into people's struggle to assert their identities, and alter the social structure where they desire to change their social positions and status. As a sound technology, which enables point-topoint communication, the telephone has been of interest of many in modern Turkey. Even though many have not gained the means of owning a telephone in their private spaces, regardless of the class, gender, ethnic and political identities, the telephone has always been an object of desire for different groups. In that sense it aligned different groups and individuals having different demographic characteristics and different political and social stands into a collective of potential or actual telephone subscribers. The wounded social structure, which has been fragmented into enclaves of differences, based on religious, political and ethnic self-expression has been unified in the desire of the telephone ownership. As more people and users, coming from different groups are integrated into the telephone service, they have become more and more transparent and controllable bodies for the state organs. The telephone has always functioned as the umbilical cord of the state that connects the security forces to the people and the necessary third party that eavesdrops all telephonic connections through operators and other systems of surveillance. On the other hand, the telephone system of Turkey as one of the modernizing, unifying and controlling machine of the state has historically generated collective resentment, frustration and anger on the part of the people who could not have an access to the use or possession of the telephone, whose telephonic connections were interrupted, broken or distorted due to the lack of qualified telecommunications infrastructure and who were left to feel that they lived outside the history of modern and globalized present that had presciently implemented the means of daily telephonic communication widely across different contexts.

In this special issue as well as in this paper, we make the case for the need to expand debates on the history of technologies in the non-West in order to capture the heterogeneity of use and meanings given to technologies such as the telephone. This allows a more rigorous analysis of the relationship between technologies and places where "foreign" machines, tools, or devices are domesticated and integrated into the local daily practices and imaginations of people across different social contexts. The history of technologies is never limited with the spaces where the technologies are designed, invented or produced. The very essence of technology as a social and cultural artifact rises from within the ways in which they are put in use by people as technologies respond and become responses to people's wills, purposes, desires and needs. In this regard, further research on the social history of technologies within the modernization processes of the non-West is crucially needed. Researches with a perspective that takes the users' practices and imaginations evolve through the engagement with technologies at the center of analysis would definitely enrich the understanding of the heterogeneous social relationships with technologies.

\section{Bibliography}


Ahıska, Meltem 2005. Radyonun Sihirli Kapısı: Garbiyatçılık ve Politik Öznellik. İstanbul: Metis.

Bektaş, Yakup 2000. The Sultan's Messenger: Cultural Constructions of Ottoman Telegraphy 1847-1880. Technology and Culture 91(4): 669-696

Bezaz, Yurda Güven undated. Geçmişten Günümüze Haberleşme ve PTT Tarihi. Ankara: Türkiye Haber-İş Sendikası.

Bijker, Wiebe and Trevor Pinch 2012. The Social Construction of Technological Systems: New Directions in the Sociology and History of Technology.

Massachusetts: MIT Press.

Bull, Michael 2006. Sound Connections: an aural epistemology of proximity and distance in urban culture. Environment and Planning D: Society and Space 22(1): 103- 116.

Chakravarty, Paula 2004 .Telecom, national development and the Indian State: a postcolonial critique. Media, Culture and Society 26 (2): 227-249.

Davison, Robert 1990. The Advent of the Electric Telegraph in the Ottoman Empire. In Essays in Ottoman Turks and Turkish History, 1773- 1923. Texas: University of Texas Press.

Demir, Tanju 2005. Türkiye'de Posta Telgraf ve Telefon Teşkilatının Tarihsel Gelişimi (1840-1920). Ankara: PTT Genel Müdürlüğü.

Gitelman, Lisa and Geoffrey Pingree 2003. New Media 1740-1915, Massachusetts: The MIT Press.

İhsanoğlu, Ekmeleddin 1992. Transfer of Modern Science and Technology to the Muslim World. İstanbul: IRCICA.

1995. Çağını Yakalayan Osmanlı. İstanbul: IRCICA.

Karakışla,Yavuz Selim 2008. Dersaadet Telefon Anonim Şirketi Osmaniyesi ve Müslüman Osmanlı Kadın TelefonMemureleri (1913),İstanbul: Türk Telekom.

Larkin, Brian 2004. Degraded Images, Distorted Sounds: Nigerian Video and the Infrastructure of Piracy. Public Culture 16(2): 289-314.

Latour, Bruno 2002. Aramis or the Love of Technology, London: Harvard University Press.

Lewis, Bernard 2002. The Emergence of Modern Turkey, Oxford: Oxford University Press. 
Onay, Aliye 1995. Türkiye'de Telefon Teşkilatının Kuruluşu. In Çağını Yakalayan Osmanlı, ed. E. İhsanoğlu and M. Kaçar. İstanbul: IRCICA.

Rafael, Vicente 2003. The Promise of the Foreign: Nationalism and the Technics of Translation in the Spanish Philippines, Durham: Duke University Press.

Ronell, Avital 1989. The Telephone Book: Technology, Schizophrenia, Electric Speech. Nebraska: University of Nebraska Press.

Mumford, Lewis 1963 Technics and Civilization. New York: Harcourt Brace Jovanovich.

Navaro-Yashin, Yael 2002. Faces of the State: Secularism and Public Life in Turkey. Princeton: Princeton University Press.

Sterne, Jonathan 2003.The Audible Past: Cultural Origins of Sound Reproduction. Durham: Duke University Press.

Stone , Allucquere Rosanne 2001. The War of Desire and Technology at the Close of the Mechanical Age. Massachusetts: MIT Press.

The 7th The State Development Plans (1996)

http://ekutup.dpt.gov.tr/plan/vii/plan7.pdf. Accessed December 2013.

Newpapers (Daily)

Hürriyet 22 May 1959.

Hürriyet 28 May 1960.

Hürriyet 3 April 1972.

Hürriyet 1 March 1973.

Milliyet. 10 September 1953.

Milliyet 1 October 1982.

Milliyet 24 April 1986.

Vakit. 21 December 1877. 